\title{
NEGATIVE IMPACT PREVENTION TO THE ENVIRONMENT ON ILLEGAL COMMUNITY MINING TOWARD COMMAND AND CONTROL APPROACH ${ }^{\Omega}$
}

\author{
Fenty U. Puluhulawa \\ Gorontalo State University \\ E-mail: fentyp@yahoo.com
}

\begin{abstract}
This article aims to analyze the need for local government policies to curb the problem of mining area which is illegally indicated. This study uses normative juridical approach. The results showed the need to command and control approach in solving the problem of artisanal mining. Artisanal mining which is doing illegally potentially damaging to the environment, conflict potentially and other negative impacts, so it needs to be managed according to the legislation. Therefore, the role of local government is required to minimize the impact caused by illegal gold mining activities. This approach is expected to control illegal mining through regulatory mechanisms, as well as an active role in conducting surveillance. This approach is expected to provide legal certainty for artisanal mining.
\end{abstract}

Keywords: command and control, illegal mining, envirnmental law

\begin{abstract}
Abstrak
Artikel ini bertujuan untuk menganalisis perlunya kebijakan pemerintah daerah dalam menertibkan persoalan pertambangan rakyat yang terindikasi dilakukan secara illegal. Penelitian ini menggunakan metode pendekatan yuridis normatif. Hasil penelitian menunjukkan perlunya pendekatan command and control (atur dan awasi) dalam menyelesaikan persoalan pertambangan rakyat. Pertambangan rakyat yang dilakukan secara illegal berpotensi merusak lingkungan, menimbulkan konflik serta dampak negative lainnya, sehingga perlu dikelola sesuai peraturan perundang-undangan. Oleh sebab itu peran pemerintah daerah dibutuhkan untuk meminimalkan dampak yang ditimbulkan oleh kegiatan pertambangan emas tanpa izin. Pendekatan ini diharapkan dapat mengendalikan pertambangan illegal melalui mekanisme pengaturan, serta peran dalam melakukan pengawasan. Pendekatan ini diharapkan dapat memberikan jaminan kepastian hukum bagi pertambangan rakyat.
\end{abstract}

Kata Kunci: command and control, pertambangan illegal, hukum lingkungan.

\section{Introduction}

Paragraph 33 article 3 of Indonesia's 1945 constitution explains that, lands and water including all natural resources content are controlled by the state and greatly used for people welfare. In line with that, there is Act No. 4 of 2009 concerning Mining of Minerals and Coals (red: UUPMB). In UUPMB, it is explained that minerals and coals resides in Indonesia's jurisdiction area are expected to give significant benefits for national economics to achieve welfare and prosperity for all justly and supports sustainable development of the region. Marilang said

This article source from Hibah Bersaing research result which sponsored by DP2M Dikti year 2013 with contract number 89/UN47.D2/PL/2013 and year 2014 with contract number 58/UN47.D2/PL/2014. that mine is priceless natural resources, thus it must be managed well to optimize its use for people welfare. ${ }^{1}$ Regulation of minerals and coals mining in an Act give binding power to all Indonesian citizens. Another issue that rise is on implementation level, which is not implemented yet. Mining is become national problem, including environmental issue caused by illegal mining. Anauthorized action of community mining always being concern for their potential in causing negative impact.

Province of Gorontalo, has gold mining potentials spread in several region. As time goes 
by, the number of community mining is also increased. Secunder data from Gorontalo Province Mining Department in 2013 shows the distribution of community mining are located in 15 region within several regency. Estimated to cope a 272 ha area with various mining system. Collier and Hoffler believe that great amount of natural resources can increase conflict potential. ${ }^{2} \mathrm{Min}$ ing activity without any authorization can inflict internal harm among miners within mining location. Mining with no safety consideration can cause victim if the mining hole collapse. The use of chemicals with no control pollute the water near mining location and cause severe health issue in local community. Not to mention, illegal mining also damage the environment.

Mining activity is really potential in causing environmental damage. Government role is to maintain environment quality within their jurisdiction. Thus, government must put pro-per environment quality as their priority. ${ }^{3}$

Command and Control can be used as a solution, eventhough some parties might have different views about this. Richard B. Steward stated that:"...command and control measures that require or prescribe specific conduct by regulated firm. Commands are enforced through order, injuctions, civil penalties, and criminal fines". ${ }^{4}$

Command and control approach has essential value, as a solution in preventing negative impact of illegal community mining. Under this mechanism regional governments are able to rule and make regulation concerning community mining which is indicated or potentially illegal. Supervision is really needed in here. It become an instrument that can measure obedience level of people towards assigned regulation. This solution is expected to reduce negative impact of illegal community mining.

\footnotetext{
Iim Halimatusa'diyah, “Desentralisasi dan Hydropolitics: Water Conflict In Indonesia", Jurnal Demokrasi dan HAM, Vol. 10, 2013, Jakarta: The Habibie Centre, page 6.

3 Marhaeni Ria Siombo, "Tanggung Jawab Pemda terhadap Kerusakan Lingkungan Hidup Kaitannya dengan Kewenangan Perizinan di Bidang Kehutanan dan Pertambangan", Jurnal Dinamika Hukum, Vol. 14 No. 3, September 2014, Purwokerto: Law Faculty of Jenderal Soedirman University, page 1.
}

\section{Problems}

To what extend command and control approach is needed in preventing negative impact of illegal mining to the environment?

\section{Method of Research}

This research used normative approach by analyzing current rule and regulation and conceptual approach. All data were obtained from primary and secondary law materials. Primary law materials are case-related Act. Secondary law materials are any publication and books of related study. The data then analyzed using qualitative-descriptive method.

\section{Discussion}

\section{Command and Control Approach in Environ- mental Law}

There are several approach model that can be used in environmental law in order to gain obedience from environmental law subject. ${ }^{5}$ These models are necessary to ensure the sustainability of our development system. Some popular approach model that we might known are command and control approach, economic approach, behavior approach, and public pressure approach. ${ }^{6}$ Each approach has their own strength and weakness. Thus require different implementation strategy.

Command and control approach however is focusing the control through law product and supervision towards its implementation. It means that control through regional regulation become the main strategy in controlling local community mining. It also support UUPMB implementation in form of regional regulation.

Enactment of UUPMB create fundamental changes in minerals and coal mining sector. The changes of contract of work system into permit system put government at higher potition than permit's receiver. In previous system, contract

\footnotetext{
4 Suparto Wijoyo, 2005, Refleksi Matarantai Pengaturan Hukum Pengelolaan Lingkungan Secara Terpadu (Studi Kasus Pencemaran Udara), Surabaya: Airlangga University Press, page 122.

5 Sukanda Husin, 2009, Penegakan Hukum Lingkungan Indonesia, Jakarta: Sinar Grafika, page 139.

6 Ibid, page 140.
} 
of work (CoW), government and mining management from foreign or local company are at the same position through agreement that bind both parties who make the deals. ${ }^{7}$

According to Muchtar Kusumaatmadja, seeing from law aspect, law itself is not only consist of principle and norms, but also institution, process and mechanism that support law. Relation of law and institution means law must be treated with authority that is regulated in any assignment Act. Its function is to ensure the content of mentioned authority. ${ }^{8}$ Along with this Romly Atmasasmita said that law can be used as renewing tools and development tools. ${ }^{9}$ Therefore in order to create law in real life this approach is needed, then law can works in our people.

Command and Control Approach as a Solution ini Minimizing Negative Impact of Illegal Community Mining towards Environment.

Illegal mining, popularly known as anauthorized mining (PETI), become quite a problem in several region of Indonesia, include the Province of Gorontalo. The existence of mineral resources in this area will give positive value if it can be managed well following the assignned Act. One of the way is by preventing its negative impact to environment.

Command and control approach is a solution offered to manage gold mining in this area. The possibility to implement this approach has been regulated in Act no. 4 of 2009 concerning Minerals and Coal Mining, but seeing the implementation level, there are some region which is still under expectancy. UUPMB normatively give the authority to regional government to create regional regulation as law instrument to overcome community mining issue which is indicated as illegal. In paragraph 6 of UUPMB stated that Government sets mining area after coordinate

Fenty Puluhulawa,“ Pengawasan sebagai Instrumen Penegakan Hukum Pada Pengelolaan Usaha Pertambangan Mineral dan Batubara", Jurnal Dinamika Hukum, Vol. 11, No 2, May 2011, Purwokerto: Law Faculty of Jenderal Soedirman University, page 296.

8 Gatot Dwi Hendro Wibowo,"Aspek Hukum dan Kelembagaan dalam Peningkatan Efisiensi dan Efektifitas Pengelolaan Wilayah Pesisir", Jurnal Hukum, Vol 16 No. 1, Ja- with regional government and consult with Indonesian Parliament. The area in which community mining already work on are prioritized to be set as community mining area (paragraph 24). Criteria of settlement area for community mining must consider the regulation stated in Paragraph 22 of UUPMB: the existence of secondary stock of minerals in river or river banks, primary stock of mineral resources, terrace sedimentary, maximum allowed-area for community mining is 25 ha, types of mining commodity, and has been worked out for 15 years as community mining are. Based on those criteria, it is clear that authorized community mining area can be settled from an already exist community mining as long as they meet the requirements mentioned in the Act.

The settlement of community mining area can ease the control and identification of community mining existence. The difficulties in identifying community mining existence is because of their remote location. Beside, the owner of mine is not always there in mining location when the officials come to check. There is no sign of mining activity, make it looks like already abandoned. This condition is indeed need to be ended by setting up community mining location.

After mining has been settled, Government needs to regulate permit mechanism for community mining. UUPMB has given the authority to regional government in permit regulation, hence right and obligation of the miners and the regional government as the one who give permission. In this situation, government permit become preventing instrument, permission given will be instrument to measure obedience level of community mining actor in running their activity. Regulation on mechanism process not only minimizing conflict and accident, but also reduce negative impact to environment. Government permit give certainty of law for the permit

nuary 2009, Yogyakarta: Law Faculty of Islamic Indonesia State University, page 2.

Sulaiman," Kearifan Tradisional dalam Pengelolaan Sumber Daya Perikanan di Aceh Pada Era Otonomi Khusus", Jurnal Dinamika Hukum, Vol. 11, No. 2, May 2011, Purwokerto: Law Faculty of Jenderal Soedirman University, page 292. 
owner, personally or in group to run their mining business. One fundamental point of permit is forbidden action, except for certain purpose with certain condition. ${ }^{10}$ Regulation of permit is expected to change the pattern of community mining which is usually done without authorization into legal mining. Maximum allowable mining area for individual (paragraph 68) is 1 hectare, for group of people is 5 hectare, for cooperative is 10 hectare. Permit issued for 5 years active time and can be renewed after that.

Control mechanism through law product in region will show that law is instrument of social changing. Related to this condition, Lawrence Friedman, whether law cause social changing, or follow social changing process? Or social changing in big community affect law system? Whether law system is a mere system which adapt to or accommodate great changing that occur outside law system itself. In this condition law is following social changing and adapt to that changes. ${ }^{11}$

The condition described previously shows the importance of law planning as an effort to solve regulation problem related to community mining, so it can follow the development and social changes in society. Seeing great mining potential of this area, it is a must for government to create any policy to manage it. There are six law instruments that can be used to make it real, they are environment quality standard, permit, AMDAL, environment audit, supervision and sanction. ${ }^{12}$ Command and control approach is focusing on government's role in governing through those 6 law instrument, as shown below.

In line with the previous explanation, regional government can implement the solution through following policies: Make proportionate community mining area in spatial planning; Make regional regulation concerning community mining that covers all component of law instrument that command through environment quality standard, permit and AMDAL; Implementing

10 Dahlia Kusuma Dewi, et al., "Izin Lingkungan dalam Kaitannya dengan Penegakan Administrasi Lingkungan dan Pidana Lingkungan Berdasarkan Undang-undang Nomor 32 Tahun 2009 Tentang Perlindungan dan Pengelolaan Lingkungan Hidup (UUPPLH)", USU Law Journal, Vol. II, No. 1, January 2014, Sumatera Utara: Master and Docto- the regulation in environment audit, supervision and commitment in giving law sanction to all violators.

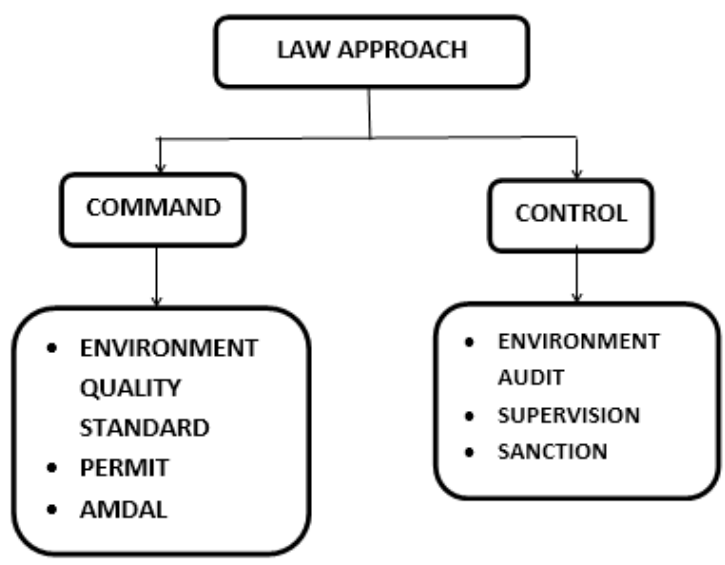

Those policies afore mentioned are expected to become fundamental projection of development in mining sector, especially community mining which aims to: Development of community mining sector considering mine's potential and regional development to improve people welfare; Boost up the development of mining sector to accelerate regional development with considering sustainability of environment, and regulate permit mechanism in mining sector; Run supervision and control to all stakeholder in implementing mining business, to keep the sustainability of environment and improve people welfare. One of the solution to stop those mining issue is control the permit given and doing cooperative supervision.

\section{Closing \\ Conclusion}

Based on the discussion, it can be concluded that "command and control approach" can be implemented by government in order to minimize negative impact of illegal mining using forcing-nature of law instrument to set quality standard of environment, permission and environmental impact analysis (AMDAL). Further,

rate Study Program, Law Faculty of North Sumatera University, page 127.

11 Hasbir Paserangi, "Perlindungan Hukum Hak Cipta Software Program Komputer Di Indonesia", Jurnal Hukum, Vol. 18, Special Edition, October 2011, Yogyakarta: Law Faculty of Indonesian Islamic University, page 30.

12 Sukanda Husin, op.cit, page 140 
implementation of control through environment audit, supervision and sanction for all violator. Therefore, regional government can implement this approach through several regulation in their region. This action is expected to give certainty of law to legalize those community mining which is labelled as illegal all these time. And finally this approach is expected to reduce negative impact of illegal mining to environment.

\section{References}

Dewi, Dahlia Kusuma., et al,. "Izin Lingkungan dalam Kaitannya dengan Penegakan Administrasi Lingkungan dan Pidana Lingkungan Berdasarkan Undang-undang No-mor 32 Tahun 2009 tentang Perlindungan dan Pengelolaan Lingkungan Hidup (UUPPLH)" USU Law Journal. Vol. II, No.1, January 2014. Sumatera Utara: Mater and Doctorate Study Program of North Sumatera University;

Puluhulawa, Fenty. "Pengawasan sebagai Instrumen Penegakan Hukum pada Pengelolaan Usaha Pertambangan Mineral dan Batubara". Jurnal Dinamika Hukum. Vol.11, No. 2, May 2011. Purwokerto: Law Faculty of Jenderal Sudirman University;

Wibowo, Gatot Dwi Hendro. "Aspek Hukum dan Kelembagaan dalam Peningkatan Efisiensi dan Efektifitas Pengelolaan Wilayah Pesisir”. Jurnal Hukum. Vol. 16, No. 1, January 2009. Yogyakarta: Law Faculty of Indonesian Islamic University;
Paserangi, Hasbir. "Perlindungan Hukum Hak Cipta Software Program Komputer di Indonesia". Jurnal Hukum. Vol 18, Special Edition. October 2011. Yogyakarta: Law Faculty of Indonesian Islamic University;

Halimatusa'diyah, lim. "Desentralisasi dan Hydropolitics: Water Conflict in Indonesia". Jurnal Demokrasi Dan HAM, Vol. 10, 2013. Jakarta: The Habibie Centre;

Siombo, Marhaeni Ria. "Tanggung Jawab Pemda terhadap Kerusakan Lingkungan Hidup Kaitannya dengan Kewenangan Perizinan di Bidang Kehutanan dan Pertambangan". Jurnal Dinamika Hukum, Vol. 14 No. 3, September 2014. Purwokerto: Law Faculty of Jenderal Soedirman University;

Marilang. "Pengelolaan Sumber Daya Alam Tambang”. Jurnal Al-Risalah. Vol.11, No. 1, May 2011. Makassar: Alaudin Islamic State University;

Husin, Sukanda. 2009. Penegakan Hukum Lingkungan Indonesia. Jakarta: Sinar Grafika;

Sulaiman. "Kearifan Tradisional dalam Pengelolaan Sumber Daya Perikanan di Aceh pada Era Otonomi Khusus". Jurnal Dinamika Hukum. Vol. 11, No. 2, May 2011. Purwokerto: Law Faculty of Jenderal Soedirman University;

Wijoyo, Suparto. 2005. Refleksi Matarantai Pengaturan Hukum Pengelolaan Lingkungan Secara Terpadu (Studi Kasus Pencemaran Udara). Surabaya: Airlangga University Press. 